\title{
PENINGKATAN EFEKTIFITAS PEMBELAJARAN KIMIA PADA MATERI KSP DAN KOLOID MELALUI IMPLEMENTASI LESSON STUDY DI SMA YUPPENTEK TANGERANG
}

Sondang N. Sihombing ${ }^{1}$, Muktiningsih Nurjayadi ${ }^{2}$ Novianti Mantasha $^{3}$, Toton Sutono ${ }^{4}$

1.2,3 Program studi Pendidikan Kimia, Jurusan Kimia, Fakultas Matematika dan IImu Pengetahuan

Alam, Universitas Negeri Jakarta, ${ }^{4}$ SMA Negeri 7 Tangerang dan SMA Yuppentek 1 Tangerang,

\begin{abstract}
Abstrak
Penelitian ini bertujuan untuk meningkatkan efektivitas pembelajaran Ksp dan koloid siswa SMA Yuppentek 1 Tangerang.melalui implementasi Lesson Study. Sampel yang digunakan adalah satu kelas XI IPA dari enam kelas XI IPA yang ada di sekolah tersebut. Penelitiian dilakukan sebanyak lima siklus, dan setiap siklus terdiri dari tiga tahapan, yaitu tahap perencanaan (plan), tahap pelaksanaan (do), dan tahap refleksi (see) untuk memberikan tanggapan dan gambaran tentang hasil pelaksanaan. Indikator ketercapaian yang digunakan untuk mengetahui efektivitas pembelajaran pada penelitian ini adalah aktivitas siswa, interaksi siswa, kepuasan siswa, keterlaksanaan pembelajaran oleh siswa, dan keterlaksanaan pembelajaran oleh guru. Tiap pertemuan siswa diberikan angket untuk mengetahui tanggapan siswa mengenai pembelajaran yang dilakukan. Hasil angket siswa dan hasil pengamatan observer dianalisis lebih lanjut sehingga diperoleh data yang akurat tentang ketercapaian indikator peneltian yang disyaratkan. Hasil penelitian menunjukkan adanya peningkatan ketercapaian indikator efektivitas pembelajaran dari siklus pertama ke siklus kedua, dan seterusnya. Berdasarkan hasil yang diperoleh dapat disimpulkan bahwa Lesson study dapat meningkatkan efektivitas pembelajaran Ksp dan koloid siswa di SMA Yuppentek 1 Tangerang.

Kata kunci : Efektivitas pembelajaran, Lesson Study, Ksp dan Koloid.
\end{abstract}

\section{Pendahuluan}

Prestasi belajar merupakan salah satu tolok ukur untuk mengetahui keberhasilan belajar seseorang. Seorang yang prestasinya tinggi dapat dikatakan bahwa ia telah berhasil dalam belajar. Prestasi belajar adalah tingkat pengetahuan sejauh mana siswa memahami materi yang telah dipelajari. Penelitian ini bertujuan untuk mendapatkan informasi sejauh mana siswa mengetahui dan memahami pelajaran serta mendapatkan informasi tentang kegiatan pembelajaran kimia khususnya materi Ksp dan Koloid di sekolah. Salah satu faktor dalam tercapainya keberhasilan kegiatan pembelajaran adalah faktor internal yaitu factor yang berasal dari diri siswa, baik berupa minat, bakat, ketertarikan siswa terhadap pelajaran, motivasi, serta tingkat intelegensi. Motivasi dan ketertarikan siswa dalam kegiatan pembelajaran sangat memengaruhi proses dan hasil belajar siswa. Permasalahan yang muncul belakangan ini adalah berkurangnya motivasi belajar siswa, jika motivasi belajar siswa kurang secara tidak langsung proses belajar tidak akan maksimal, pembelajaran tidak belangsung efektif dan akhirnya akan memengaruhi hasil belajar siswa. Motivasi belajar siswa juga dipengaruhi oleh materi yang dipelajari. Pada materi yang kurang disenangi siswa, motivasi belajar akan berkurang, sehingga mengakibatkan proses pembelajaran tidak berlangsung efektif seperti yang diharapkan.

Selain faktor internal, faktor eksternal atau faktor dari luar diri siswa juga dapat memengaruhi proses belajar. Faktor 
tersebut adalah faktor metode pembelajaran dan lingkungan.

Selain siswa, unsur terpenting yang ada dalam kegiatan pembelajaran adalah guru. Guru sebagai pendidik bertanggung jawab untuk memberikan ilmu pengetahuan sekaligus menmbimbing pemahaman nilai-nilai, akhlak, moral maupun social.

Untuk menjalankan peran tersebut seorang guru dituntut untuk memiliki pengetahuan dan wawasan yang luas. Guru dapat mengetahui masalah yang dihadapi selama proses pembelajaran melalui pengkajian pembelajaran sehingga dapat melakukan review terhadap kinerjanya.

Hasil evaluasi diri atau review tersebut selanjutnya digunakan sebagai masukan untuk memperbaiki kinerjanya dan juga dapat meningkatkan kualitas pembelajaran. Salah satu cara melakukan pengkajian proses pembelajaran adalah melalui Lesson Study.

Slamet Mulyana mengemukakan ada tiga tahapan dalam Lesson Study, yaitu : (1) Perencanaan (Plan); (2) Pelaksanaan (Do) dan Refleksi (See).

\section{a. Tahapan Perencanaan (Plan)}

Dalam tahap perencanaan, para guru yang tergabung dalam Lesson Study berkolaborasi untuk menyusun Rencana Pelaksanaan Pembelajaran (RPP). Perencanaan yang disusun harus mencerminkan pembelajaran yang berpusat pada siswa. Perencanaan di awali dengan kegiatan menganalisis

kebutuhan dan permasalahan yang dihadapi dalam pembelajaran, seperti: kompetensi dasar, cara membelajarkan siswa, mensiasati kekurangan fasilitas dan sarana belajar, dan sebagainya, sehingga dapat ketahui berbagai kondisi nyata yang akan digunakan untuk kepentingan pembelajaran. Selanjutnya, secara bersama-sama pula dicarikan solusi untuk memecahkan segala permasalahan yang ditemukan. Kesimpulan dari hasil analisis kebutuhan dan permasalahan menjadi bagian yang harus dipertimbangkan dalam penyusunan RPP, sehingga RPP menjadi sebuah perencanaan yang benar-benar sangat matang, yang didalamnya sanggup mengantisipasi segala kemungkinan yang akan terjadi selama pelaksanaan pembelajaran berlangsung, baik pada tahap awal, tahap inti sampai dengan tahap akhir pembelajaran.

\section{b. Tahapan Pelaksanaan (Do)}

Pada tahapan yang kedua, terdapat dua kegiatan utama yaitu: (1) kegiatan pelaksanaan pembelajaran yang dilakukan oleh salah seorang guru yang disepakati atau atas permintaan sendiri untuk mengimplementasikan RPP yang telah disusun bersama, selanjutnya guru tersebut disebut sebagai guru model, (2) kegiatan pengamatan atau observasi yang dilakukan oleh anggota atau komunitas Lesson Study yang lainnya (guru, kepala sekolah, atau pengawas sekolah, atau undangan lainnya yang bertindak sebagai 
pengamat atau observer). Dalam kegiatan observasi Lesson Study perlu ditekankan bahwa yang menjadi pusat kajian adalah aktivitas siswa, bukan mencari kesalahan yang dilakukan oleh guru model.

\section{c. Tahapan Refleksi (See)}

Tahap ini sangat penting karena upaya perbaikan proses pembelajaran selanjutnya akan bergantung dari ketajaman analisis para observer berdasarkan pengamatan terhadap pelaksanaan pembelajaran yang telah dilaksanakan. Kegiatan refleksi dilakukan dalam bentuk diskusi yang diikuti seluruh peserta Lesson Study yang dipandu oleh kepala sekolah atau peserta lainnya yang ditunjuk. Diskusi dimulai dari penyampaian kesan-kesan guru model yang telah mengimplementasikan RPP yang disusun secara kolaborasi, dengan menyampaikan komentar atau kesan umum maupun kesan khusus atas proses pembelajaran yang dilakukannya, misalnya mengenai kesulitan dan permasalahan yang dirasakan dalam mengimplementasikan RPP yang telah disusun. Selanjutnya, semua pengamat menyampaikan tanggapan atau saran secara bijak terhadap proses pembelajaran yang telah dilaksanakan (pusat kajian adalah aktivitas yang dilakukan siswa, bukan kesalahan yang mungkin dilakukan oleh guru mode). Dalam menyampaikan saransaranya, pengamat harus didukung oleh bukti-bukti yang diperoleh dari hasil pengamatan, tidak berdasarkan opininya. Berbagai pembicaraan yang berkembang dalam diskusi dapat dijadikan umpan balik bagi seluruh peserta untuk kepentingan perbaikan atau peningkatan proses pembelajaran. Oleh karena itu, sebaiknya seluruh peserta pun memiliki catatan-catatan pembicaraan yang berlangsung dalam diskusi. Dari hasil refleksi dapat diperoleh sejumlah pengetahuan baru atau keputusankeputusan penting guna perbaikan dan peningkatan proses pembelajaran, baik pada tataran indiividual, maupun menajerial. Pada tataran individual, berbagai temuan dan masukan berharga yang disampaikan pada saat diskusi dalam tahapan refleksi tentunya menjadi modal bagi para guru, baik yang bertindak sebagai guru model maupun observer untuk mengembangkan proses pembelajaran ke arah lebih baik.

Melihat pentingnya pembinaan komunitas belajar melalui Lesson study, pada penelitian ini dilakukan pengkajian dalam meningkatkan efektivitas pembelajaran kimia siswa pada materi kelarutan, hasil kali kelarutan dan koloid melalui implementasi Lesson Study. Efektivitas pembelajaran kimia yang diteliti mencakup indikator aktivitas siswa, interaksi siswa, kepuasan siswa, keterlaksanaan pembelajaran oleh siswa, dan keterlaksanaan pembelajaran oleh guru.

\section{Metode Penelitian}

Metode penelitian yang digunakan dalam kajian Lesson study ini adalah 
penelitian deskriptif kualitatif. Lesson study secara umum terdiri atas 3 tahap, yaitu tahap perencanaan (plan), tahap pelaksanaan (do), dan tahap refleksi (see). Pelaksanaan penelitian untuk meningkatkan efektivitas pembelajaran di $\begin{array}{llll}\text { SMA } & \text { Yupentek } & 1 & \text { Tangerang }\end{array}$ dilaksanakan sebanyak lima siklus. Jumlah siswa yang dijadikan subjek belajar adalah satu kelas dengan jumlah 37 siswa dari 6 kelas yang ada.

Pada setiap siklus dilakukan tiga tahap yang menjadi karakteristik Lesson study, yaitu plan, do dan see. Pelaksanaan kegiatan pada tiap siklus secara umum diuraikan di bawah ini:

\section{a. Perencanaan (Plan)}

Identifikasi

masalah

pada

pembelajaran Ksp dan Koloid. Identifikasi dilakukan dengan melihat berbagai aspek, yaitu : kondisi siswa, keadaan kelas yang akan digunakan untuk kegiatan Lesson study, karakteristik materi kelarutan dan hasil kali kelarutan serta koloid, alternative metode yang akan digunakan pada proses pembelajaran, bahan dan alat yang diperlukan, evaluasi yang dilakukan, perencanaan jumlah open lesson yang akan dilaksanakan, media yang sesuai dalam pelaksanaan proses pembelajaran, lembar observasi yang disusun berdasarkan pada indikator ketercapaian, menentukan jumlah observer, orang yang bertugas sebagai observer, serta pemilihan guru model. Dalam tahap perencanaan ini seluruh anggota tim merancang perencanaan secara kolaboratif melalui diskusi bersama. Hasil kesepakatan yang diperoleh, selanjutnya akan diimplentasikan pada saat pelaksnaan prose pembelajaran atau $D o$.

\section{Pelaksanaan Open lesson (Do)} Seorang guru dari anggota tim Lesson study yang disepakati untuk memberikan pembelajaran atau guru model bertugas mengimplementasikan rencana pelaksanaan pembelajaran yang telah dibuat bersama. Anggota tim lainnya serta guru-guru lain yang bukan merupakan tim Lesson study menjadi pengamat (observer) yang bertugas mengamati jalannya seluruh kegiatan yang berlangsung. Siswa-siswi yang terdapat dalam kelas yang diteliti diberi nomor sehingga observer mengamati siswa berdasarkan nomor siswa. Observer mengamati berdasarkan lembar observasi yang telah dibuat sebelumnya pada saat plan.

\section{Refleksi (See)}

Setelah kegiatan pelaksanaan usai, seluruh anggota tim Lesson study dan para pengamat lainnya berkumpul untuk melaksanakan refleksi atau pembahasan dari kegiatan pelaksanaan open lesson. Pada tahap ini guru model menyampaikan kesan-kesannya selama melaksanakan pembelajaran dengan Lesson study. Para pengamat juga menyampaikan semua yang diamati yaitu aktivitas siswa, interaksi siswa, kepuasan siswa, keterlaksanaan pembelajaran oleh 
siswa dan guru pada saat pelaksanaan pembelajaran berlangsung. Dari refleksi ini, semua hal dan telah disampaikan tadi jika terdapat kekurangan dan kesulitan dibahas dan diberikan solusi penyelesaiannya.

Hal-hal tersebut dijadikan bahan acuan untuk memperbaiki kegiatan Lesson study pada siklus selanjutnya serta sebagai bahan masukan berharga untuk guru model dan para pengamat dalam melaksanakan pembelajaran.

\section{Hasil dan Pembahasan \\ a. Siklus ke-1 \\ 1. Tahapan Perencanaan (Plan)}

Perencanaan diawali dengan kegiatan menganalisis kebutuhan dan permasalahan yang dihadapi dalam pembelajaran. Dari hasil diskusi, wawancara, dan observasi, diketahui bahwa siswa-siswi dalam kelas kurang efektif dalam pembelajaran. Pada tahap ini disusun RPP yang sesuai dengan kondisi kelas. Materi pada pertemuan ini adalah Larutan Jenuh, metode yang digunakan adalah ceramah, diskusi, dan pemberian tugas.

\section{Tahapan Pelaksanaan (Do)}

Guru model yang telah ditentukan pada tahap perencanaan bertugas untuk melaksanakan pembelajaran sesuai dengan RPP. Sedangkan observer bertugas untuk mengamati jalannya pembelajaran, observer hanya mengamati tingkah laku siswa berdasarkan lembar observasi yang ada, observer tidak mengganggu jalannya pembelajaran. Kelas yang diteliti terdiri dari 37 orang siswa, setiap siswa dalam kelas tersebut diberi nomor sehingga observer mengamati siswa berdasarkan nomor siswa.

\section{Tahapan Refleksi (See)}

Pada open lesson ke-1 ini, berdasarkan hasil observasi dan catatan lapangan diperoleh data bahwa siswasiswi pada 30 menit pertama mengikuti pembelajaran dengan baik, namun pada 30 menit kedua sekitar $23 \%$ siswa belum menyimak dengan benar pembelajaran kimia hari ini, dari hasil observasi masih ada siswa yang hanya diam saja tidak mencatat dan menyimak pembelajaran, siswa dengan nomor 15 terlihat bosan. Siswa yang terlihat aktif berinteraksi hanya siswa dengan nomor 21 dan 4

b. Siklus ke-2

1. Tahapan Perencanaan (Plan)

Seperti pada pertemuan pertama, peneliti, guru kimia, dan observer membuat Rencana Pelaksanaan Pembelajaran (RPP) secara bersamasama. Materi pertemuan kedua adalah Pengaruh Ion Sejenis, metode yang digunakan adalah ceramah, diskusi, dan pemberian tugas.

\section{Tahapan Pelaksanaan (Do)}

Guru membuka pelajaran dengan memberikan pertanyaan mengenai Ksp, siswa dengan nomor 12 menjawab pertanyaan dari guru dengan tepat. Guru memeriksa tugas yang diberikan pertemuan sebelumnya, siswa dengan 
nomor $15, \quad 21, \quad 12, \quad 17, \quad$ dan 25 mengerjakan tugas pertemuan sebelumnya di papan tulis.

Guru menjelaskan materi berikutnya yaitu pengaruh ion senama, siswa menyimak dan mencatat penjelasan guru. Siswa mengerjakan soal-soal dari buku paket yang diperintahkan oleh guru.

Siswa dengan nomor 6, 24, 13, dan 1 mengerjakan soal di papan tulis. Siswa dengan nomor 13 menjawab kurang tepat dan diperbaiki oleh siswa dengan nomor 12. Pertemuan ini diakhiri dengan pemberian tugas oleh guru, siswa mencatat apa yang disampaikan oleh guru.

\section{Tahapan Refleksi (See)}

Pada open lesson ke-2 ini, siswasiswi sudah mengalami peningkatan dalam pembelajaran, mereka menyimak dengan benar pembelajaran kimia. Namun, dari hasil observasi masih ada sekitar $22 \%$ siswa yang tidak mencatat dan menyimak pembelajaran dengan serius. Siswa dengan nomor 15 pada pertemuan ini tampak lebih bersemangat dibandingkan pertemuan sebelumnya.

\section{c. Siklus ke-3}

1. Tahapan Perencanaan (Plan)

Sama halnya seperti open lesson sebelumnya, pada tahap ini dilakukan penyusunan RPP dari hasil refleksi pada open lesson sebelumnya. Materi pertemuan ketiga adalah Pembentukan Endapan, metode yang digunakan adalah ceramah, diskusi, dan pemberian tugas.

\section{Tahapan Pelaksanaan (Do)}

Guru memeriksa tugas yang diberikan pada pertemuan sebelumnya, siswa dengan nomor 12 dan 15 mengerjakan tugas rumah di papan tulis tanpa disuruh. Kemudian guru memberikan soal-soal mengenai kelarutan dari pertemuan pertama, siswa mengerjakan soal yang diberikan dan menjawabnya di papan tulis sesuai dengan nomor kocokan yang keluar. Siswa dengan nomor 24, 17, 36, 9, dan 14 mendapat nomor kocokan dan mengerjakannya di papan tulis, siswa dengan nomor 9 kurang tepat mengerjakan jawaban, dan diperbaiki oleh siswa dengan nomor 12. Guru menjelaskan mengenai pengendapan dan memberikan soal. Siswa mengerjakan soal yang diberikan dan menjawabnya di papan tulis sesuai dengan nomor kocokan, sama seperti sebelumnya. Siswa dengan nomor $8,19,26,19$, dan 34 mendapat nomor kocokan dan mengerjakannya di papan tulis.

\section{Tahapan Refleksi (See)}

Pada open lesson ke-3 ini, banyak siswa-siswi yang bergerak berpindah tempat duduk, karena open lesson kali ini adalah mengerjakan latihan soal yang diberikan. Siswa-siswi Nampak antusias dan bersemangat pada pembelajaran hari ini. Namun perhatian terhadap guru berkurang karena siswa sibuk dengan soal-soal yang diberikan.

d. Siklus ke-4

1. Tahapan Perencanaan (Plan) 
Seperti pada pertemuan sebelumnya, peneliti, guru kimia, dan observer membuat Rencana Pelaksanaan Pembelajaran (RPP) secara bersamasama. Materi pertemuan ini adalah koloid, dengan metode yang digunakan adalah diskusi, presentasi, dan pemberian tugas.

\section{Tahapan Pelaksanaan (Do)}

Guru membuka kelas dengan memberikan pertanyaan singkat mengenai larutan, siswa menjawab dengan serempak, dan siswa dengan nomor 12 menjawab dengan jelas. Guru membagi kelas menjadi 6 kelompok. Kelompok pertama dan keempat membahas tentang larutan, koloid, dan suspensi. Kelompok kedua dan kelima membahas tentang klasifikasi koloid. Kelompok ketiga dan keenam membahas tentang sifat-sifat koloid. Kelompok. Pembelajaran hari ini berlangsung sangat tertib dan siswa antusias. Semua siswa aktif berdiskusi.

\section{Tahapan Refleksi (See)}

Pada open lesson ke-4 ini, siswasiswi sangat antusias dan bersemangat pada pembelajaran hari ini. Siswa nomor dengan nomor 24, 19, dan 7 nampak tidak aktif ikut berdiskusi. Hal ini kemungkinan karena siswa tersebut tidak dilibatkan diskusi oleh teman sekelompoknya.

\section{e. Siklus ke-5 \\ 1. Tahapan Perencanaan (Plan) \\ Seperti seperti pertemuan} sebelumnya, peneliti, guru kimia, dan observer membuat Rencana Pelaksanaan
Pembelajaran (RPP) secara bersamasama. Materi pertemuan ini adalah koloid, dengan metode yang digunakan adalah diskusi, presentasi, dan pemberian tugas.

\section{Tahapan Pelaksanaan (Do)}

Guru membuka pelajaran dengan memberikan pertanyaan awal mengenai perbedaan larutan, koloid, dan suspense. Guru berkeliling mengawasi jalannya presentasi, siswa kelompok pertama mengawali presentasi. Guru menjadi moderator saat tanya jawab berlangsung, siswa aktif dalam tanya jawab. Guru mempersilakan kelompok kedua untuk presentasi. Setelah itu dilanjutkan dengan kelompok ketiga. Saat pembelajaran berakhir Guru menutup pertemuan dan siswa membereskan kelas seperti semula

\section{Tahapan Refleksi (See)}

Pada open lesson ke-5 ini, siswasiswi sangat antusias dan bersemangat pada pembelajaran hari ini. Siswa-siswi sangat aktif dalam diskusi, tanya jawab berlangsung antar siswa-siswi yang presentasi dengan siswa-siswi yang berada di tempat duduknya masingmasing juga berlangsung tertib.

Berdasarkan perolehan data didapat rata-rata efektivitas pembelajaran siswa cenderung meningkat dari pertemuan yang satu ke pertemuan berikutnya, Paparan data dalam bentuk grafik tentang ketercapaian indikator efektivitas dipaparkar pada gambar 1 : 
Aktivitas rata-rata siswa pada open lesson pertama sebesar $64,9 \%$ meningkat menjadi $67,7 \%$, namun terjadi penurunan pada open lesson ketiga yaitu 62,2\% dan meningkat menjadi $66,4 \%$ dan terakhir $65,4 \%$. Interaksi siswa meningkat dari $68,1 \%$ menjadi $68,1 \%, \quad 68,2 \%$, $68,5 \%$, dan 67,6\%. Kepuasaan siswa terlihat dari $85,1 \%, 83,2 \%, 72,2 \%, 85,5 \%$, dan $86,9 \%$.
Aktivitas siswa dan rasa puan siswa pada open lesson 2-3 mengalami penurunan, namun meningkat secara signifikan pada pertemuan 4 dan 5 . Interaksi siswa cenderung mengalami peningkatan mulai pertemuan 1 sampai pertemuan 5. Secara umum indikator efektivitas pembelajaran mengalami peningkatan dari open lesson 1 sampai open lesson 5

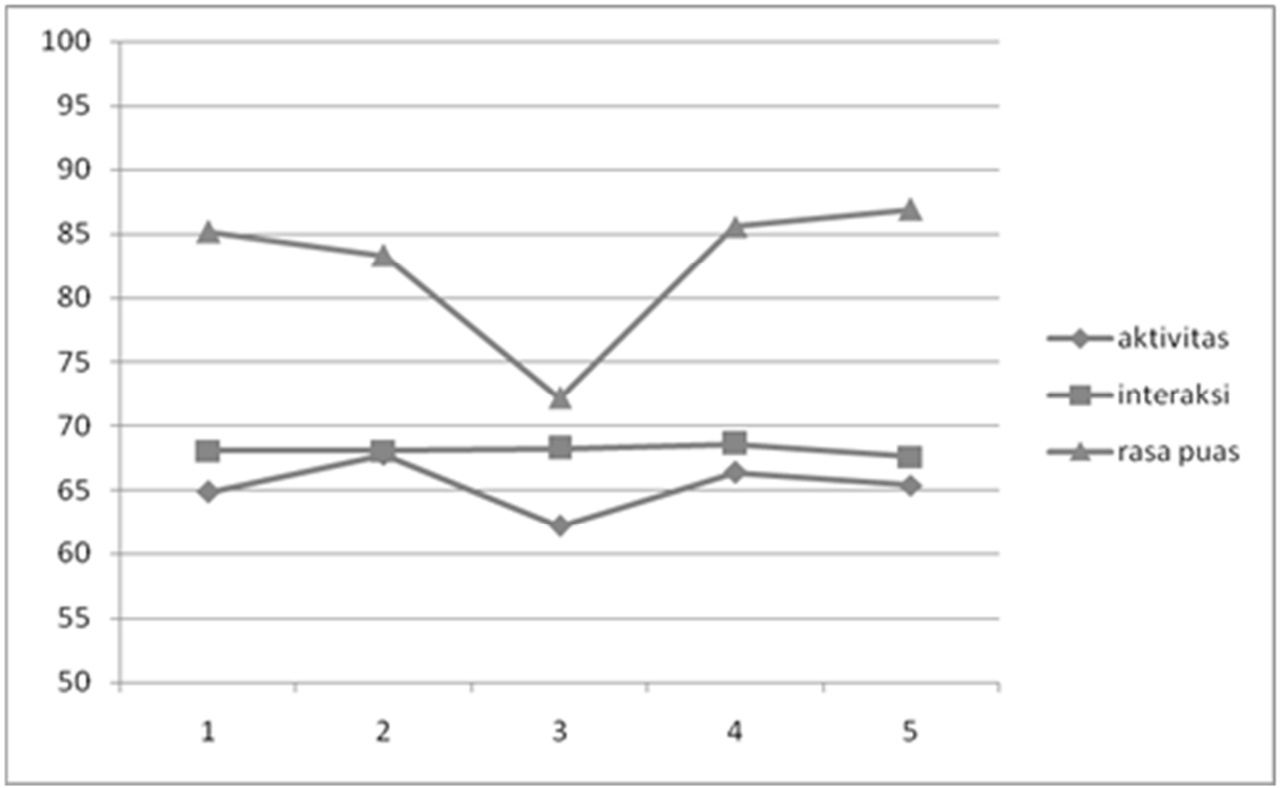

Gambar 1. Grafik ketercapaian indikator efektivitas pada proses penbelajaran yang dilakukan pada lima kali open lesson.

\section{Kesimpulan dan Saran}

a. Kesimpulan

dapat disimpulkan bahwa efektivitas pembelajaran kimia siswa dengan indikator aktivitas siswa, interaksi siswa, kepuasan siswa, keterlaksanaan pembelajaran oleh siswa, dan keterlaksanaan pembelajaran oleh siswa guru pada materi kelarutan dan hasil kali kelarutan serta koloid dapat ditingkatkan melalui implementasi Lesson Study.

b. Saran

Untuk penelitian selanjutnya dapat disarankan penelitian dalam kegiatan pembelajaran melalui Lesson Study berbasis Musyawarah Guru Mata Pelajaran (MGMP). 


\section{DAFTAR PUSTAKA}

Mulyana, Slamet. 2007. Lesson Study (Makalah). Kuningan: LPMP-Jawa Barat 